\title{
INITIAL VOCABULARY ANALYSIS OF NOUNS IN THE FIELD OF LEGAL STUDIES
}

\author{
Sri Utami \\ University of Kutai Kartanegara \\ sriutami@unikarta.ac.id
}

Submit, 29-11-2019 Accepted, 30-12-2019 Publish, 30-12-2019

\begin{abstract}
The purpose of this research is to analyze initial vocabulary of nouns in the field of Legal Studies had by the first semester students of Law Study Program of University of Kutai Kartanegara in academic year 2019/2020. This study used descriptive qualitative design. The research subjects were 10 students of the first semester. The instrument of the study was vocabulary test in the form of written test by using match type test. The results of this study are as follows: (1) there were 9 words that became the most common initial vocabularies of nouns in the field of Legal Studies, (2) There were 6 words that became the most unfamiliar nouns for almost all the students. Based on the findings of the research it could be summarized (1) the initial vocabularies of nouns in the field of Legal Studies were varies but still very limited; (2) the nouns in the field of Legal Studies that were not familiar for the students were also varies. It meant that each student has different familiar and unfamiliar nouns. The initial vocabularies of nouns in the field of Legal Studies had by the students were different one each other. Some students had more initial vocabularies but some others had less initial vocabularies.
\end{abstract}

Keywords: initial vocabularies, nouns, legal studies

\section{INTRODUCTION}

English learners usually find their limited number and knowledge of vocabulary as an obstacle in the way of their success in academic discourse. The learning of vocabulary is an important part in foreign language learning. The meanings of new words are very frequently emphasized, whether in books or in verbal communication. If learners lack vocabulary knowledge, they soon discover that their ability to comprehend or express themselves clearly is limited (Decarrico, 2001; Nation, 2001 cited in Susanto, 2017).

Based on a research done by Mozaffari \& Moini (2014), Pakistani students, being non-native speakers of English and belonging to ESL context, at all academic levels are assumed to have very limited vocabulary knowledge which might be a factor influencing their proficiency in academic discourse. 
Investigating, measuring and analyzing the mastery, the size and the level of vocabulary of the students are the kinds of research that have been done by many researchers in many countries. A study that aimed to measure the vocabulary size of pre-university students at a public university in Malaysia was done by Ibrahim, (2013). It was found that there was a strong relationship $(\mathrm{r}=0.737)$ between English language proficiency and vocabulary size, statistically significant at $\mathrm{p}<0.01$ level. Students' performance in receptive and productive vocabulary was also found to be strongly related $(\mathrm{r}=0.862)$, statistically significant at $\mathrm{p}<0.01$ level. The results indicated that these pre-university students have yet to achieve the recommended threshold level of vocabulary that is needed to enable them to successfully acquire vocabulary independently.

According to Jaafar, (2017) the Syrian university learners' overall vocabulary size in English was moderate $(M=5.30)$. Moreover, the scores of the learners across the fourteen 1000-word families/lists of the vocabulary test varied from high to moderate. The recent study about measuring English vocabulary size was done by Sudarman \& Chinokul (2018). The study aimed to investigate the mean vocabulary size and mastery level of English department students at University of Kutai Kartanegara. Sudarman \& Chinokul (2018) state that the students only knew about 1,273 words families. The result was still below the threshold as suggested by the vocabulary scholars and was not improved after years of learning. The finding also showed that the participants had a very low mastery level. They did not even master the 2,000 or 3,000 high frequency word level, nor the academic vocabulary level. The results indicated that the participants had a low vocabulary proficiency.

Based on the references above it can be said that vocabulary is an interesting area to be explored in a research. There are many researcher conducted in the area of teaching and learning vocabulary, vocabulary acquisition, measuring vocabulary size, etc. It is interesting to know that law has often been regarded as uniquely differently from other areas of ESP. That's why the researcher was interested to investigate the initial vocabulary in law study had by the law students. The researcher assumed that in the EFL Indonesian context, the researches on the students' vocabulary size, especially in an analysis form, were rather rare. Moreover, a research about the analysis of initial vocabulary had by the students, especially which only focused on nouns in the field of Legal Studies, has not ever been conducted before, particularly at University of Kutai Kartanegara. So, through this article the researcher wants to describe the initial vocabulary of nouns in the field of Legal Studies had by the first semester students of Law Study Program of University of Kutai Kartanegara in academic year 2019/2020. 


\section{LITERATURE REVIEW}

Vocabulary is a very important language aspect to master. Vocabulary as one of the language aspects is learnt when people learning a language. It is impossible to learn a language without vocabulary. It means the learner cannot use a language without having knowledge about vocabulary of that language. Finnochiaro (1989) says that vocabulary is a fundamental component of second language proficiency; one of the primary goals of language learning is to know the meanings of the words. It is needed to communicate successfully in the second language. The importance of mastering vocabulary in learning is also stated by Nunan, (2003) says that the development of a rich vocabulary is an important element in the acquisition of a second language.

Richards (2003) states that vocabulary is a core component of language proficiency and provides much of the basic for how well the learners speak, listen, read and write. The more students have a stock of words used in a language, the better it will make their performance. According to Lehr (2004) vocabulary is knowledge of words and words meaning in both oral and print language and in productive and receptive forms which is used in listening, speaking, reading and writing.

Learning vocabulary is dealing with the lexicon or dictionary that can show the content and function words. Content words give us the most important information while function words are used to stick those words together. The content words are words with lexical meanings that we can find in a dictionary. Function words are words that show the grammatical relationship of words in a sentence. Content words include nouns, verbs, adjectives, and adverbs. While, function words consist of determiners, auxiliaries, prepositions, conjunctions, interrogatives, and modals. It is relevant to idea from Nababan (1986) who states that English words are of two kinds: content and function words. Content words are words that have what we call lexical meanings or dictionary meanings, while function words are words that show the relationship of the word functions to make sentences proper or grammatically correct. In further discussion on content words, Nababan (1986) divides content words into four types, nouns, verbs, adjectives, and adverbs.

1. Nouns tell us which object about person, place or thing.

Examples: judge, thief, police, freedom, justice, court, police station.

2. Verbs tell us about the action happening or the state.

Examples: punish, to judge, arrest, investigate.

3. Adjectives give us details about objects and people.

Examples: tough, strong, cruel, smart, fair.

4. Adverbs tell us when, where, how often or how something is done.

Examples: yesterday, in the court, always, often, bravely. 
Aeborsold \& Field (1997) classify vocabulary into two terms, they are:

\section{Active Vocabulary}

Active Vocabulary refers to items the learner can use appropriately in speaking or writing and it is also called as productive vocabulary, although, in to put into practice. It means that to use the productive vocabulary, the students are supposed to know how to pronounce it well, they must know and be able to use grammar of the language target, they are also familiar with collocation and understand the connotation meaning of the words. This type is often use in speaking and writing skill. In order to give the proficiency in spoken and written language, words must continuously be added to the active vocabulary of the students. Active vocabulary of a language calls for: a) The use of right word in right place, b) the spontaneous recall of words, c) grammatical accuracy i.e., use of correct tenses, inflections and word order, d) in speech, fluency and ability to reproduce correct sounds, pronunciation, intonation, rhythm etc.

\section{Passive Vocabulary}

Passive vocabulary refers to a language items that can be recognized and understand in the context of reading and listening and also called as receptive vocabulary. Passive vocabulary or comprehension consists of the words comprehended by the people, when they read and listen. We all understand what we hear on the radio or see on TV, giving us a passive vocabulary, but that doesn't mean that we use that vocabulary actively in writing or speaking. Passive vocabulary refers to the receptive side of language. Passive vocabulary calls for: a) a recognition of vocabulary in speech or writing, b) an acquaintance with major grammatical items or forms, c) the skill of stimulating rapidly the sense of large word groups.

The first semester students of Law Study Program of University of Kutai Kartanegara are expected to have a lot of vocabularies both active or passive vocabularies especially the specific nouns in the field of Legal Studies. When the students say they know a word or phrase, they could mean one of two things. First, they could mean that if someone says the word to them, they know what it means. This is passive knowledge. The second way of knowing is that they can recall and use that vocabulary appropriately. This is active knowledge. This isn't anything to do with active or passive vocabulary in grammar. It's about how they store their memory of a word for later use, and there is a large, important difference. With passive vocabulary, they can listen and understand. Simply being aware of this distinction can make a huge difference in their learning. If they are not aware that passive and active vocabulary are very different things, there is a risk that they will become one of the many people who can read and listen to a language very well, but can speak or write very little of it. A good communicator tries to turn passive vocabulary into active vocabulary. It is obvious that words 
from passive vocabulary shift to active vocabulary after some years. There is no hard and fast rule of acquiring active vocabulary.

It is interesting to investigate what initial words the first semester students of Law Study Program already have especially for the specific terminologies of nouns in the field of Legal Studies. The students are expected to have been familiar with the words tested. By having these vocabularies, it is assumed that the students will find it is easier to take the English lessons because the subject matter will use a lot of specific terms in the field of Legal Studies.

\section{RESEARCH METHOD}

The design of this research is descriptive qualitative, since the researcher provides the results and findings in a descriptive form. In this research, the researcher used descriptive qualitative because in this research the researcher did not look for scores and the relationship between variables, but only took the data and analyzed the initial words the first semester students of Law Study Program already have especially for the specific terminologies of nouns in the field of Legal Studies using descriptive qualitative.

The subjects of this study are ten students of the first semester of Law Study Program of Kutai Kartanegara University. The ten students were chosen from one class that was class A. The students were taken purposively based on the need and they are studied in depth.

The instrument of this research was test that was vocabulary test in the form of written test. The researcher used matched test. The items of the test were taken from the subject matter of English lesson for the first semester students of Law Study Program. The vocabulary test was about to match 25 specific nouns in the field of Legal Studies with the correct Indonesian meanings. Each student must match all English words that they could recognize and know with the Indonesian meanings. The researcher gave 30 minutes for the students to complete the test. In doing the test the students were not allowed to open dictionaries or use their gadgets.

Basrowi \& Suwandi (2008) state that in qualitative research, the researcher him/herself or with the help of others is primary data collection tool. It means the researcher should find out the research data by herself, collects, analyzes, interprets, verifies, and concludes the data using her knowledge. The data of this study are qualitative data of the students' works on vocabulary test. To collect the data, the researcher followed some procedures as follows: First, the researcher came to class A and selected ten students from class A to be used as subjects in this research. Second, the researcher gave them vocabulary test. Third, the researcher asked the students to read silently the items and asked them to comprehend the words in the test, after that the researcher asked them to match all 
words that they could recognize and know. They had to give the Indonesian meanings for all words tested by matching them. They were not allowed to open dictionary or use their gadgets. The time to finish the test was 30 minutes. They had to do by themselves, individually.

The data of this study were the students' works on vocabulary test. In analyzing the data, the researcher followed the procedures from Miles \& Hubberman (1994), started with data reduction, data display and verification/data conclusion. The researcher analyzed the students' answers about specific nouns in the field of Legal Studies. The analysis was focused on the correct and incorrect answers given by the students in the test. By analyzing the correct answers of the test, the researcher will find the initial vocabularies of nouns in the field of Legal Studies that the students already have. By answering the questions correctly, it is assumed that the students have already known and had those vocabularies. It means those words have become their initial vocabulary for the students. By analyzing the incorrect answers, the researcher will find the difficult vocabularies for the students. By answering the questions incorrectly, it is assumed that the students have not been familiar with those words.

\section{FINDING}

Findings of the study are directed to describe the results of analysis of initial vocabulary of nouns in the field of Legal Studies had by the first semester students of Law Study Program of University of Kutai Kartanegara and nouns in the field of Legal Studies that are not familiar for the students. The findings are explained into two subs point, they are: (1) findings on the initial vocabularies the first semester students of Law Study Program already have especially for the specific terminologies of nouns in the field of Legal Studies; (2) finding on nouns in the field of Legal Studies that are not familiar for the students.

The steps of analysis of this research were described as follows: first, the researcher checked the students' answers carefully by using the key answers of the test and organized the answers in the table. Then, the researcher analyzed the data by using the analysis tools. The purpose was to identify data. Second, after the identification by using the key answers of the test, the researcher interpreted the results in tabulation to make the results easier to understand also added some analyses representation for the conclusion of the whole answers that made by the first semester students of Law Study Program of University of Kutai Kartanegara

\section{Findings on the Initial Vocabularies of Nouns in the Field of Legal Studies Had by the Students}

Based on the results of vocabulary test, the researcher analyzed the findings on the initial vocabularies of nouns in the field of Legal Studies. The findings on the initial vocabularies of nouns in the field of Legal Studies had by 
the students can be seen on table 1 below. The data showed the words and the total of nouns in the field of Legal Studies had by 10 students as the subject.

Table 1. The Initial Vocabularies of Nouns in the Field of Legal Studies Had by the Students

\begin{tabular}{|c|c|c|}
\hline $\begin{array}{l}\text { Number of } \\
\text { Students }\end{array}$ & $\begin{array}{c}\text { Initial Vocabularies } \\
\text { (Correct Answers) }\end{array}$ & Indonesian Meanings \\
\hline 1 & $\begin{array}{l}\text { 1. lawyer } \\
\text { 2. court } \\
\text { 3. police } \\
\text { 4. prosecutor } \\
\text { 5. constitution } \\
\text { 6. penitentiary } \\
\text { 7. judge } \\
\text { 8. smuggler } \\
\text { 9. police investigator } \\
\text { 10. defendant } \\
\text { 11. article } \\
\text { 12. Criminal Law Book } \\
\text { 13. Code of Civil Law } \\
\text { 14. prisoner } \\
\text { 15. fugitive } \\
\text { 16. police station } \\
\text { 17. investigation } \\
\text { 18.Notice of Termination of } \\
\text { Investigation } \\
\text { 19. The Supreme Court } \\
\text { 20. The Corruption Eradication } \\
\text { Commission } \\
\text { 21. The Ministry of Law and Human } \\
\text { Right }\end{array}$ & $\begin{array}{l}\text { 1. pengacara } \\
\text { 2. pengadilan } \\
\text { 3. polisi } \\
\text { 4. jaksa } \\
\text { 5. Undang-Undang } \\
\text { 6. penjara } \\
\text { 7. hakim } \\
\text { 8. penyelundup } \\
\text { 9. polisi penyidik } \\
\text { 10. terdakwa } \\
\text { 11. pasal } \\
\text { 12. KUHPidana } \\
\text { 13. KUHPerdata } \\
\text { 14. tahanan } \\
\text { 15. buronan } \\
\text { 16. kantor polisi } \\
\text { 17. penyelidikan } \\
\text { 18. SP3 } \\
\text { 19. Mahkamah Agung } \\
\text { 20. KPK } \\
\text { 21. Kemenkumham }\end{array}$ \\
\hline & TOTAL WORDS: 21 & \\
\hline 2 & $\begin{array}{l}\text { 1. lawyer } \\
\text { 2. police } \\
\text { 3. judge } \\
\text { 4. smuggler } \\
\text { 5. police investigator } \\
\text { 6. Criminal Law Book } \\
\text { 7. Code of Civil Law } \\
\text { 8. prisoner } \\
\text { 9. police station } \\
\text { 10. investigation } \\
\text { 11. Notice of Termination of } \\
\text { Investigation } \\
\text { 12. The Corruption Eradication } \\
\text { Commission } \\
\text { 13. The Attorney General's Office } \\
\text { 14. The Ministry of Law and Human } \\
\text { Right }\end{array}$ & $\begin{array}{l}\text { 1. pengacara } \\
\text { 2. polisi } \\
\text { 3. hakim } \\
\text { 4. penyelundup } \\
\text { 5. polisi penyidik } \\
\text { 6. KUHPidana } \\
\text { 7. KUHPerdata } \\
\text { 8. tahanan } \\
\text { 9. kantor polisi } \\
\text { 10. penyelidikan } \\
\text { 11. SP3 } \\
\text { 12. KPK } \\
\text { 13. Kejaksaan Agung } \\
\text { 14. Kemenkumham }\end{array}$ \\
\hline
\end{tabular}




\begin{tabular}{|c|c|c|}
\hline & \multicolumn{2}{|l|}{ TOTAL WORDS: 14} \\
\hline \multirow[t]{23}{*}{3} & 1. lawyer & 1. pengacara \\
\hline & 2. court & 2. pengadilan \\
\hline & 3. police & 3. polisi \\
\hline & 4. prosecutor & 4. jaksa \\
\hline & 5. prosecutor attorney & 5. Jaksa Penuntut Umum \\
\hline & 6. penitentiary & 6. penjara \\
\hline & 7. judge & 7. hakim \\
\hline & 8. smuggler & 8. penyelundup \\
\hline & 9. police investigator & 9. polisi penyidik \\
\hline & 10. defendant & 10. terdakwa \\
\hline & 11. Code of Civil Law & 11. KUHPerdata \\
\hline & 12. prisoner & 12. tahanan \\
\hline & 13. fugitive & 13. buronan \\
\hline & 14. police station & 14. kantor polisi \\
\hline & 15. investigation & 15. penyelidikan \\
\hline & 16. Notice of Termination of & 16. SP3 \\
\hline & Investigation & 17. Mahkamah Agung \\
\hline & 17. The Supreme Court & 18. Pengadilan Tinggi Negeri \\
\hline & 18. The State High Court & 19. KPK \\
\hline & 19. The Corruption Eradication & 20. Kemenkumham \\
\hline & Commission & \\
\hline & 20. The Ministry of Law and Human & \\
\hline & TOTAL WORDS: 20 & \\
\hline \multirow[t]{18}{*}{4} & 1. lawyer & 1. pengacara \\
\hline & 2. court & 2. pengadilan \\
\hline & 3. police & 3. polisi \\
\hline & 4. prosecutor & 4. jaksa \\
\hline & 5. penitentiary & 5. penjara \\
\hline & 6. judge & 6. hakim \\
\hline & 7. police investigator & 7. polisi penyidik \\
\hline & 8. Criminal Law Book & 8. KUHPidana \\
\hline & 9. prisoner & 9. tahanan \\
\hline & 10. police station & 10. kantor polisi \\
\hline & 11. investigation & 11. penyelidikan \\
\hline & 12. Notice of & 12. SP3 \\
\hline & Investigation & 13. KPK \\
\hline & 13. The Corruption Eradication & 14. Kemenkumham \\
\hline & Commission & \\
\hline & 14. The Ministry of Law and Human & \\
\hline & Kignil & \\
\hline & TOTAL WORDS: 14 & \\
\hline \multirow[t]{6}{*}{5} & 1. lawyer & 1. pengacara \\
\hline & 2. court & 2. pengadilan \\
\hline & 3. police & 3. polisi \\
\hline & 4. prosecutor & 4. jaksa \\
\hline & 5. penitentiary & 5. penjara \\
\hline & 6. judge & 6. hakim \\
\hline
\end{tabular}




\begin{tabular}{|c|c|c|}
\hline & $\begin{array}{l}\text { 7. smuggler } \\
\text { 8. police investigator } \\
\text { 9. defendant } \\
\text { 10. Criminal Law Book } \\
\text { 11. prisoner } \\
\text { 12. fugitive } \\
\text { 13. judiciary } \\
\text { 14. police station } \\
\text { 15. investigation } \\
\text { 16. Notice of Termination of } \\
\text { Investigation } \\
\text { 17. The Supreme Court } \\
\text { 18. The State High Court } \\
\text { 19. The Corruption Eradication } \\
\text { Commission } \\
\text { 20. The Ministry of Law and Human } \\
\text { Right }\end{array}$ & $\begin{array}{l}\text { 7. penyelundup } \\
\text { 8. polisi penyidik } \\
\text { 9. terdakwa } \\
\text { 10. KUHPidana } \\
\text { 11. tahanan } \\
\text { 12. buronan } \\
\text { 13. kejaksaan } \\
\text { 14. kantor polisi } \\
\text { 15. penyelidikan } \\
\text { 16. SP3 } \\
\text { 17. Mahkamah Agung } \\
\text { 18. Pengadilan Tinggi Negeri } \\
\text { 19. KPK } \\
\text { 20. Kemenkumham }\end{array}$ \\
\hline & TOTAL WORDS: 20 & \\
\hline 6 & $\begin{array}{l}\text { 1. lawyer } \\
\text { 2. court } \\
\text { 3. police } \\
\text { 4. prosecutor } \\
\text { 5. constitution } \\
\text { 6. penitentiary } \\
\text { 7. police investigator } \\
\text { 8. police station } \\
\text { 9. investigation } \\
\text { 10. Notice of Termination of } \\
\text { Investigation } \\
\text { 11. The Corruption Eradication } \\
\text { Commission } \\
\text { 12. The Attorney General's Office } \\
\text { 13. The Ministry of Law and Human } \\
\text { Right }\end{array}$ & $\begin{array}{l}\text { 1. pengacara } \\
\text { 2. pengadilan } \\
\text { 3. polisi } \\
\text { 4. jaksa } \\
\text { 5. Undang-Undang } \\
\text { 6. penjara } \\
\text { 7. polisi penyidik } \\
\text { 8. kantor polisi } \\
\text { 9. penyelidikan } \\
\text { 10. SP3 } \\
\text { 11. KPK } \\
\text { 12. Kejaksaan Agung } \\
\text { 13. Kemenkumham }\end{array}$ \\
\hline & TOTAL WORDS: 13 & \\
\hline 7 & $\begin{array}{l}\text { 1. lawyer } \\
\text { 2. court } \\
\text { 3. police } \\
\text { 4. prosecutor } \\
\text { 5. prosecutor attorney } \\
\text { 6. constitution } \\
\text { 7. penitentiary } \\
\text { 8. judge } \\
\text { 9. smuggler } \\
\text { 10. police investigator } \\
\text { 11. defendant } \\
\text { 12. article } \\
\text { 13. Criminal Law Book } \\
\text { 14. Code of Civil Law } \\
\text { 15. prisoner }\end{array}$ & $\begin{array}{l}\text { 1. pengacara } \\
\text { 2. pengadilan } \\
\text { 3. polisi } \\
\text { 4. jaksa } \\
\text { 5. Jaksa Penuntut Umum } \\
\text { 6. Undang-Undang } \\
\text { 7. penjara } \\
\text { 8. hakim } \\
\text { 9. penyelundup } \\
\text { 10. polisi penyidik } \\
\text { 11. terdakwa } \\
\text { 12. pasal } \\
\text { 13. KUHPidana } \\
\text { 14. KUHPerdata } \\
\text { 15. tahanan }\end{array}$ \\
\hline
\end{tabular}




\begin{tabular}{|c|c|c|}
\hline & $\begin{array}{l}\text { 16. fugitive } \\
\text { 17. judiciary } \\
\text { 18. police station } \\
\text { 19. investigation } \\
\text { 20. Notice of Termination of } \\
\text { Investigation } \\
\text { 21. The Corruption Eradication } \\
\text { Commission } \\
\text { 22. The Attorney General's Office } \\
\text { 23. The Ministry of Law and Human } \\
\text { Right }\end{array}$ & $\begin{array}{l}\text { 16. buronan } \\
\text { 17. kejaksaan } \\
\text { 18. kantor polisi } \\
\text { 19. penyelidikan } \\
\text { 20. SP3 } \\
\text { 21. KPK } \\
\text { 22. Kejaksaan Agung } \\
\text { 23. Kemenkumham }\end{array}$ \\
\hline & TOTAL WORDS: 23 & \\
\hline 8 & $\begin{array}{l}\text { 1. lawyer } \\
\text { 2. police } \\
\text { 3. judge } \\
\text { 4. smuggler } \\
\text { 5. police investigator } \\
\text { 6. Criminal Law Book } \\
\text { 7. Code of Civil Law } \\
\text { 8. prisoner } \\
\text { 9. police station } \\
\text { 10. investigation } \\
\text { 11. Notice of Termination of } \\
\text { Investigation } \\
\text { 12. The Corruption Eradication } \\
\text { Commission } \\
\text { 13. The Ministry of Law and Human } \\
\text { Right }\end{array}$ & $\begin{array}{l}\text { 1. pengacara } \\
\text { 2. polisi } \\
\text { 3. hakim } \\
\text { 4. penyelundup } \\
\text { 5. polisi penyidik } \\
\text { 6. KUHPidana } \\
\text { 7. KUHPerdata } \\
\text { 8. tahanan } \\
\text { 9. kantor polisi } \\
\text { 10. penyelidikan } \\
\text { 11. SP3 } \\
\text { 12. KPK } \\
\text { 13. Kemenkumham }\end{array}$ \\
\hline & TOTAL WORDS: 13 & \\
\hline 9 & $\begin{array}{l}\text { 1. lawyer } \\
\text { 2. court } \\
\text { 3. police } \\
\text { 4. prosecutor } \\
\text { 5. prosecutor attorney } \\
\text { 6. penitentiary } \\
\text { 7. judge } \\
\text { 8. smuggler } \\
\text { 9. police investigator } \\
\text { 10. defendant } \\
\text { 11. Criminal Law Book } \\
\text { 12. prisoner } \\
\text { 13. fugitive } \\
\text { 14. judiciary } \\
\text { 15. police station } \\
\text { 16. investigation } \\
\text { 17. Notice of Termination of } \\
\text { Investigation } \\
\text { 18. The Supreme Court } \\
\text { 19. The State High Court } \\
\text { 20. The Corruption Eradication }\end{array}$ & $\begin{array}{l}\text { 1. pengacara } \\
\text { 2. pengadilan } \\
\text { 3. polisi } \\
\text { 4. jaksa } \\
\text { 5. Jaksa Penuntut Umum } \\
\text { 6. penjara } \\
\text { 7. hakim } \\
\text { 8. penyelundup } \\
\text { 9. polisi penyidik } \\
\text { 10. terdakwa } \\
\text { 11. KUHPidana } \\
\text { 12. tahanan } \\
\text { 13. buronan } \\
\text { 14. kejaksaan } \\
\text { 15. kantor polisi } \\
\text { 16. penyelidikan } \\
\text { 17. SP3 } \\
\text { 18. Mahkamah Agung } \\
\text { 19. Pengadilan Tinggi Negeri } \\
\text { 20. KPK } \\
\text { 21. Kemenkumham }\end{array}$ \\
\hline
\end{tabular}




\begin{tabular}{|c|c|c|}
\hline & $\begin{array}{l}\text { Commission } \\
\text { 21. The Ministry of Law and Human } \\
\text { Right }\end{array}$ & \\
\hline & TOTAL WORDS: 21 & \\
\hline \multirow[t]{2}{*}{10} & $\begin{array}{l}\text { 1. lawyer } \\
\text { 2. police } \\
\text { 3. prosecutor } \\
\text { 4. police investigator } \\
\text { 5. defendant } \\
\text { 6. prisoner } \\
\text { 7. police station } \\
\text { 8. investigation } \\
\text { 9. Notice of Termination of Investigation } \\
\text { 10. The State High Court } \\
\text { 11. The Corruption Eradication } \\
\text { Commission Attorney General's Office } \\
\text { 12. The } \\
\text { 13. The Ministry of Law and Human } \\
\text { Right }\end{array}$ & $\begin{array}{l}\text { 1. pengacara } \\
\text { 2. polisi } \\
\text { 3. jaksa } \\
\text { 4. polisi penyidik } \\
\text { 5. terdakwa } \\
\text { 6. tahanan } \\
\text { 7. kantor polisi } \\
\text { 8. penyelidikan } \\
\text { 9. SP3 } \\
\text { 10. Pengadilan Tinggi Negeri } \\
\text { 11. KPK } \\
\text { 12. Kejaksaan Agung } \\
\text { 13. Kemenkumham }\end{array}$ \\
\hline & TOTAL WORDS: 13 & \\
\hline
\end{tabular}

Findings on Nouns in the Field of Legal Studies that are not Familiar for the Students

Based on the data from the students' works on vocabulary test, the researcher found that the students were not familiar with some nouns tested in the field of Legal Studies. It was proven by looking the incorrect answers given by the students. To make it clear the researcher tabulated the incorrect answers in table 2 as follows:

Table 2. The Incorrect Answers Made by the Students.

\begin{tabular}{|c|c|c|}
\hline $\begin{array}{c}\text { Number of } \\
\text { the } \\
\text { Students }\end{array}$ & $\begin{array}{c}\text { The Words } \\
\text { (The Unfamiliar Words) }\end{array}$ & $\begin{array}{c}\text { Incorrect Indonesian } \\
\text { Meanings } \\
\text { (Incorrect Answers) }\end{array}$ \\
\hline \multirow[t]{5}{*}{1} & 1. prosecutor attorney & 1. kejaksaan \\
\hline & 2. judiciary & 2. Jaksa Penuntut Umum \\
\hline & 3. The State High Court & 3. Kejaksaan Agung \\
\hline & 4. The Attorney's General Office & 4. Kepresidenan \\
\hline & TOTAL: 4 WORDS & \\
\hline \multirow[t]{6}{*}{2} & 1. court & 1. jaksa \\
\hline & 2. prosecutor & 2. kejaksaan \\
\hline & 3. prosecutor attorney & 3. pengacara \\
\hline & 4. constitution & 4. pengadilan \\
\hline & 5. penitentiary & 5. jaksa \\
\hline & 6. defendant & 6. buronan \\
\hline
\end{tabular}




\begin{tabular}{|c|c|c|}
\hline & 7. article & 7. Undang-Undang \\
\hline & 8. fugitive & 8. pasal \\
\hline & 9. judiciary & 9. Jaksa Penuntut Umum \\
\hline & 10. The Supreme Court & 10. Kejaksaan Agung \\
\hline & 11. The State High Court & 11. MPR \\
\hline & \multicolumn{2}{|l|}{ TOTAL: 11 WORDS } \\
\hline \multirow[t]{6}{*}{3} & 1. constitution & 1. * \\
\hline & 2. article & 2. Undang-Undang \\
\hline & 3. Criminal Law Book & 3. KUHPerdata \\
\hline & 4. judiciary & 4. pengadilan \\
\hline & 5. The Attorney General's Office & 5. * \\
\hline & \multicolumn{2}{|l|}{ TOTAL: 5 WORDS } \\
\hline \multirow[t]{12}{*}{4} & 1. prosecutor attorney & 1. penjara \\
\hline & 2. constitution & 2. penjara \\
\hline & 3. smuggler & 3. pasal \\
\hline & 4. defendant & 4. buronan \\
\hline & 5. article & 5. KUHPerdata \\
\hline & 6. Code of Civil Law & 6. Jaksa Penuntut Umum \\
\hline & 7. fugitive & 7. Undang-Undang \\
\hline & 8. judiciary & 8. pengadilan \\
\hline & 9. The Supreme Court & 9. Jaksa Agung \\
\hline & 10. The State High Court & 10. MA \\
\hline & 11. The Attorney General's Office & 11. DPA \\
\hline & \multicolumn{2}{|l|}{ TOTAL: 11 WORDS } \\
\hline \multirow[t]{6}{*}{5} & 1. prosecutor attorney & 1. $*$ \\
\hline & 2. constitution & 2. pengadilan \\
\hline & 3. article & 3. Undang-Undang \\
\hline & 4. Code of Civil Law & 4. $*$ \\
\hline & 5. The Attorney General's Office & 5. BPK \\
\hline & \multicolumn{2}{|l|}{ TOTAL: 5 WORDS } \\
\hline \multirow[t]{12}{*}{6} & 1. prosecutor attorney & 1. * \\
\hline & 2. judge & 2. pasal \\
\hline & 3. smuggler & 3. * \\
\hline & 4. defendant & 4. $*$ \\
\hline & 5. article & 5. * \\
\hline & 6. Criminal Law Book & 6. penyelidikan \\
\hline & 7. Code of Civil Law & 7. Undang-Undang \\
\hline & 8. prisoner & 8. $*$ \\
\hline & 9. fugitive & 9. * \\
\hline & 10. judiciary & $10 *$ \\
\hline & 11. The Supreme Court & 11. * \\
\hline & 12. The State High State & 12. MA \\
\hline
\end{tabular}




\begin{tabular}{|c|c|c|}
\hline 7 & $\begin{array}{l}\text { 1. The Supreme Court } \\
\text { 2. The State High Court }\end{array}$ & $\begin{array}{l}\text { 1. Pengadilan Tinggi Negeri } \\
\text { 2. Mahkamah Agung }\end{array}$ \\
\hline & \multicolumn{2}{|l|}{ TOTAL: 2 WORDS } \\
\hline \multirow[t]{13}{*}{8} & 1. court & 1. jaksa \\
\hline & 2. prosecutor & 2. kejaksaan \\
\hline & 3. prosecutor attorney & 3. pengacara \\
\hline & 4. constitution & 4. pengadilan \\
\hline & 5. penitentiary & 5. jaksa \\
\hline & 6. defendant & 6. buronan \\
\hline & 7. article & 7. Undang-Undang \\
\hline & 8. fugitive & 8. pasal \\
\hline & 9. judiciary & 9. Jaksa Penuntut Umum \\
\hline & 10. The Supreme Court & 10. Jaksa Agung \\
\hline & 11. The State High Court & 11. Kejaksaan Agung \\
\hline & 12. The Attorney General's Office & 12. Kepresidenan \\
\hline & \multicolumn{2}{|l|}{ TOTAL: 12 WORDS } \\
\hline \multirow[t]{5}{*}{9} & 1. constitution & 1. pasal \\
\hline & 2. article & 2. Undang-Undang \\
\hline & 3. Code of Civil Law & 3. Undang-Undang \\
\hline & 4. The Attorney General's Office & 4. Badan Pemeriksa Keuangan \\
\hline & \multicolumn{2}{|l|}{ TOTAL: 4 WORDS } \\
\hline \multirow[t]{12}{*}{10} & 1. court & 1. kejaksaan \\
\hline & 2. prosecutor attorney & 2. $*$ \\
\hline & 3. constitution & 3. penjara \\
\hline & 4. penitentiary & 4. penyelundup \\
\hline & 5. judge & 5. terdakwa \\
\hline & 6. smuggler & 6. buronan \\
\hline & 7. article & 7. Undang-Undang \\
\hline & 8. Criminal Law Book & 8. KUHPerdata \\
\hline & 9. Code of Civil Law & 9. KUHPidana \\
\hline & 10. fugitive & 10. pasal \\
\hline & 11. judiciary & 11. pengadilan \\
\hline & 12. The Supreme Court & 12. Jaksa Agung \\
\hline
\end{tabular}

\section{TOTAL: 12 WORDS}

Note: $*=$ no answer

\section{DISCUSSION}

As it has been stated before, the research aims in answering the problems of the study, they were: (1) what initial vocabularies the first semester students of Law Study Program already have especially for the specific terminologies of nouns in the field of Legal Studies; (2) what nouns in the field of Legal Studies that are not familiar for the students. 
According to Arifin (2013), there are many popular legal terms of English in Indonesian version that Indonesian students, especially law students, hopefully, have been familiar with. Some examples of the terms are: defendant, suspect, lawyer, Attorney General, Supreme Court, Law, article, Criminal Code, trial, etc. In line with Arifin (2013), Bigbanktheories.com (2016) also released the legal terms that are the most looking for by people, some of them are: Law, court, Supreme Court, Human Right, article, legal standing, plea, evidence, Criminal Code/Book of Criminal Code, Civil Law Code/Book of Civil Code, trial, advocate/lawyer/attorney, suspect, prisoner, witness, defendant, and many others.

Based on table 1, the initial vocabularies of nouns in the field of Legal Studies were varies. It meant from 25 words of nouns tested, certain initial vocabularies were owned by certain students. Only some words were had by all students. The initial vocabularies of nouns in the field of Legal Studies had by the students can be described as follows:

1. Student 1: from 25 words tested, the student had 21 words, they were: lawyer, court, police, prosecutor, constitution, penitentiary, judge, smuggler, police investigator, defendant, article, Criminal Law Book, Code of Civil Law, prisoner, fugitive, police station, investigation, Notice of Termination of Investigation, The Supreme Court, The Corruption Eradication Commission, The Ministry of Law and Human Right.

2. Student 2 had 14 words, they were: lawyer, police, judge, smuggler, police investigator, Criminal Law Book, Code of Civil Law, prisoner, police station, investigation, Notice of Termination of Investigation, The Corruption Eradication Commission, The Attorney General's Office, The Ministry of Law and Human Right.

3. Student 3 had 20 words, they were: lawyer, court, police, prosecutor, prosecutor attorney, penitentiary, judge, smuggler, police investigator, defendant, Code of Civil Law, prisoner, fugitive, police station, investigation, Notice of Termination of Investigation, The Supreme Court, The State High Court, The Corruption Eradication Commission, The Ministry of Law and Human Right.

4. Student 4 had 14 words, they were: lawyer, court, police, prosecutor, penitentiary, judge, police investigator, Criminal Law Book, prisoner, police station, investigation, Notice of Termination of Investigation, The Corruption Eradication Commission, The Ministry of Law and Human Right.

5. Student 5 had 20 words, they were: lawyer, court, police, prosecutor, penitentiary, judge, smuggler, police investigator, defendant, Criminal Law Book, prisoner, fugitive, judiciary, police station, investigation, Notice of Termination of Investigation, The Supreme Court, The State High Court, The Corruption Eradication Commission, The Ministry of Law and Human Right. 
6. Student 6 had 13 words, they were: lawyer, court, police, prosecutor, constitution, penitentiary, police investigator, police station, investigation, Notice of Termination of Investigation, The Corruption Eradication Commission, The Attorney General's Office, The Ministry of Law and Human Right.

7. Student 7 had 23 words, they were: lawyer, court, police, prosecutor, prosecutor attorney, constitution, penitentiary, judge, smuggler, police investigator, defendant, article, Criminal Law Book, Code of Civil Law, prisoner, fugitive, judiciary, police station, investigation, Notice of Termination of Investigation, The Corruption Eradication Commission, The Attorney General's Office, The Ministry of Law and Human Right.

8. Student 8 had 13 words, they were: lawyer, police, judge, smuggler, police investigator, Criminal Law Book, Code of Civil Law, prisoner, police station, investigation, Notice of Termination of Investigation, The Corruption Eradication Commission, The Ministry of Law and Human Right.

9. Student 9 had 21 words, they were: lawyer, court, police, prosecutor, prosecutor attorney, penitentiary, judge, smuggler, police investigator, defendant, Criminal Law Book, prisoner, fugitive, judiciary, police station, investigation, Notice of Termination of Investigation, The Supreme Court, The State High Court, The Corruption Eradication Commission, The Ministry of Law and Human Right,

10. Student 10 had 13 words, they were: lawyer, police, prosecutor, police investigator, defendant, prisoner, police station, investigation, Notice of Termination of Investigation, The State High Court, The Corruption Eradication Commission, The Attorney General's Office, The Ministry of Law and Human Right.

From the description above it could be seen that nobody could have all 25 words tested as their initial vocabularies. The maximum initial vocabularies had by the students were 23 words and the minimum were 13 words. There were 9 words that were had by all students, the words were: lawyer, police, police investigator, prisoner, police station, investigation, The Corruption Eradication Commission, and The Ministry of Law and Human Right. It meant that all students had been familiar with those words and the words became the most common initial vocabularies of nouns in the field of Legal Studies. It is in line with the common popular words stated and released by Arifin (2013) and Bigbanktheories.com (2016). For some words the students had been familiar because those words are famous among the people.

Next discussion is about to answer the second problem of this research, that is "What nouns in the field of Legal Studies that are not familiar for the students?". Based on table 2, the nouns in the field of Legal Studies that were not 
familiar for the first semester students were also varies. Some students were not familiar with almost half of the words tested. Only few of them knew almost all the words tested. The nouns in the field of Legal Studies that were not familiar for the students can be described as follows:

1. Student 1 had 4 unfamiliar nouns, they were: prosecutor attorney, judiciary, The State High Court, The Attorney's General Office.

2. Student 2 had 11 unfamiliar nouns, they were: court, prosecutor, prosecutor attorney, constitution, penitentiary, defendant, article, fugitive, judiciary, The Supreme Court, The State High Court.

3. Student 3 had 5 unfamiliar nouns, they were: constitution, article, Criminal Law Book, judiciary, The Attorney General's Office.

4. Student 4 had 11 unfamiliar nouns, they were: prosecutor attorney, constitution, smuggler, defendant, article, Code of Civil Law, fugitive, judiciary, The Supreme Court, The State High Court, The Attorney General's Office.

5. Student 5 had 5 unfamiliar nouns, they were: prosecutor attorney, constitution, article, Code of Civil Law, The Attorney General's Office.

6. Student 6 had 12 unfamiliar nouns, they were: prosecutor attorney, judge, smuggler, defendant, article, Criminal Law Book, Code of Civil Law, prisoner, fugitive, judiciary, The Supreme Court, The State High State,

7. Student 7 had 2 unfamiliar nouns, they were: The Supreme Court, The State High Court.

8. Student 8 had 12 unfamiliar nouns, they were: court, prosecutor, prosecutor attorney, constitution, penitentiary, defendant, article, fugitive, judiciary, The Supreme Court, The State High Court, The Attorney General's Office.

9. Student 9 had 4 unfamiliar nouns, they were: constitution, article, Code of Civil Law, The Attorney General's Office.

10. Student 10 had 12 unfamiliar nouns, they were: court, prosecutor attorney, constitution, penitentiary, judge, smuggler, article, Criminal Law Book, Code of Civil Law, fugitive, judiciary, The Supreme Court.

From the description above it could be explained that the largest total number of unfamiliar nouns had by some students was 12 words. Those words were varies. Each student has different unfamiliar nouns. There were some students that only had 2 and 4 unfamiliar nouns from 25 words tested. There were 6 words that became the most unfamiliar nouns for almost all the students. The words were: prosecutor attorney, constitution, article, judiciary, The Supreme Court, and The Attorney General's Office. Almost all the students gave the wrong answers, they did not know the Indonesian meanings of those words. It meant that 
the students were not familiar with those words. Only few of them knew the meanings of those words.

\section{CONCLUSION}

Based on the findings of the research it could be summarized (1) the initial vocabularies of nouns in the field of Legal Studies were varies but still very limited; (2) the nouns in the field of Legal Studies that were not familiar for the students were also varies. It meant that each student has different familiar and unfamiliar nouns. The initial vocabularies of nouns in the field of Legal Studies had by the students were different one each other. Some students had more initial vocabularies but some others had less initial vocabularies.

\section{REFERENCES}

Aeborsold, J., A \& Lee, M.,F. (1997). From Reader to Reading Teacher. New York: Cambridge University Press.

Arifin, R. (2013). Termonilogy of Law in English-Indonesian Version. Retrieved Desember 28, 2019, from https://ridwanbahasa.wordpress.com/tag/indonesian-and-english-legal-terms/

Basrowi \& Suwandi. (2008). Memahami Penelitian Kualitatif. Jakarta: Rineka Cipta.

Bigbanktheories.com. (2016). Istilah Hukum Dalam Bahasa Inggris Yang Banyak Dicari Orang. Retrieved December 28, 2009, from https://www.bigbanktheories.com/istilah-hukum-dalam-bahasa-inggrisyang-banyak-dicari-orang/

Finnochiaro, M. (1989). Teaching English as A Second Language. New York: Harper and Paw Publisher.

Ibrahim, (2013). Measuring the vocabulary size of Muslim pre-university students. World Applied Sciences Journal, 21 (3):44-49.

Jaafar, J., M. (2017). Article: Investigating EFL Syrian undergraduates' vocabulary size. https://www.researchgate.net/publication/322154241 Investigating EFL Syria n undergraduates' vocabulary size

Lehr. (2004). Research-Based Practices in Early Reading Series: A Focus on Vocabulary. Honolulu, Hawaii Pacific Resources for Education and Learning PREL.

Miles. M., \& Hubberman. (1994). Qualitative Data Analysis: An Expanded Sources Book. Beverly Hills: Sage Publication Inc.

Mozaffari, A., \& Moini, R. (2014). Academic words in education research articles: A corpus study.

Procedia-Social and Behavioral Sciences, 98, 1290-1296. https://doi.org/10.1016/j.sbspro.2014.03.545

Nababan, P., W., J. (1986). Buku Materi Pokok Structure IVA. Jakarta: Universitas Terbuka. 
Nunan. (2003). Practical English Language Teaching. International Edition. Singapore: McGraw-Hill.

Richards. (2003) DefinitionVocabukary. www.repo.iain-tulungagung.ac.id. Accessed on November, 2019.

Sudarman \& Chinokul, S. (2018). The English Vocabulary Size and Level of English Department Students at Kutai Kartanegara University. ETERNAL (English, Teaching, Learning, and Research Journal), 4(1), 1-12. DOI:https://doi.org/10.24252/Eternal.V41.2018.A1

Susanto, A. (2017). The Teaching of Vocabulary: A Perspective. Jurnal KATA 1(2), 182-191. DOI: 10.22216/jk.v1i2.2136 